Int. J. Electrochem. Sci., 14 (2019) 11596 - 11606

International Journal of

ELECTROCHEMICAL

SCIENCE

$\underline{\text { www.electrochemsci.org }}$

Short Communication

\title{
Corrosion Behaviour of Three Kinds of Arc Sprayed Coatings in Soil
}

\author{
Jialiang Song ${ }^{1,2}$, Zhaoliang Li ${ }^{1,2}$, Dongjiu Zhang ${ }^{4}$, Qiong Yao $^{4}$, Ziheng Bai ${ }^{1,2}$, Yali Feng ${ }^{1,2}$, \\ Chaofang Dong ${ }^{1,2}$ and Kui Xiao ${ }^{1,2 *}$ \\ ${ }^{1}$ Corrosion and Protection Center, University of Science and Technology Beijing, Beijing 100083, \\ China. \\ ${ }^{2}$ National Materials Corrosion and Protection Data Center, University of Science and Technology \\ Beijing, Beijing 100083, China. \\ ${ }^{3}$ Key Laboratory of Space Launching Site Reliability Technology, Haikou 571000, China. \\ *E-mail: xiaokui@ustb.edu.cn
}

doi: $10.20964 / 2019.12 .60$

Received: 21 June 2019 / Accepted: 25 August 2019 / Published: 29 October 2019

The corrosion resistance of a pure $\mathrm{Zn}$ coating, a $\mathrm{ZnAl}$ alloy coating and a $\mathrm{ZnAl}$ pseudo-alloy coating in a Beijing area was studied. The corrosion products were analysed by XRD, and the electrochemical processes of the three coatings were analysed by measuring the electrochemical impedance and polarization curves. The results showed that the surface corrosion products of the pure $\mathrm{Zn}$ coating were mainly composed of $\mathrm{Zn}_{5}(\mathrm{OH})_{8} \mathrm{Cl}_{2} \mathrm{H}_{2} \mathrm{O}, \mathrm{ZnCO}_{3}, \mathrm{ZnO}$ and $\mathrm{Zn}_{5}\left(\mathrm{CO}_{3}\right)_{2}(\mathrm{OH})_{6}$, while the surface corrosion products of the $\mathrm{ZnAl}$ alloy and $\mathrm{ZnAl}$ pseudo-alloy coating similarly consisted of $\mathrm{Zn}_{5}(\mathrm{OH})_{8} \mathrm{Cl}_{2} \mathrm{H}_{2} \mathrm{O}$, $\mathrm{Zn}_{0.71} \mathrm{Al}_{0.29}(\mathrm{OH})_{2}\left(\mathrm{CO}_{3}\right) 0.145 \mathrm{xH}_{2} \mathrm{O}$ and $\mathrm{ZnO} \cdot \mathrm{Al}_{2} \mathrm{O}_{3}$. Before and after corrosion, the order of the coating corrosion resistance was as follows: $\mathrm{ZnAl}$ alloy coating $>\mathrm{ZnAl}$ pseudo-alloy coating > pure $\mathrm{Zn}$ coating. It was found that a "self-sealing" protective effect of the $\mathrm{ZnAl}$ alloy coating was better than that of the $\mathrm{ZnAl}$ pseudo-alloy coating because the composition was more uniformly distribution. The main reason for a weaker "self-sealing" protective effect of the $\mathrm{ZnAl}$ pseudo-alloy was that galvanic corrosion occurred between the Zn-rich phase and the Al-rich phase of the pseudo-alloy, which accelerated the electrochemical reaction. Meanwhile, the pure Zn coating did not have the "self-sealing" effect. Consequently, the corrosion resistance of the $\mathrm{ZnAl}$ alloy coating was the best.

Keywords: Soil corrosion, Pure Zn coating, ZnAl alloy coating, ZnAl pseudo-alloy coating, Electrochemical test 
(C) 2019 The Authors. Published by ESG (www.electrochemsci.org). This article is an open access article distributed under the terms and conditions of the Creative Commons Attribution license (http://creativecommons.org/licenses/by/4.0/). 